\title{
Reflexões sobre os egressos do curso de Licenciatura em Educação do Campo da Universidade de Brasília: os elementos para "Transformar (ação) Pedagógica" na Educação Superior
}

\author{
Márcia Mariana Bittencourt Brito ${ }^{1}$, Mônica Castagna Molina ${ }^{2}$ \\ ${ }^{1}$ Universidade de Brasília - UnB. Departamento de Educação do Campo. Avenida Nossa Senhora de Fátima s/n. Planaltina- \\ DF. Brasil. ${ }^{2}$ Universidade de Brasília - UnB. \\ Autor para correspondência/Author for correspondence: marciamarianabittencourt@gmail.com
}

\begin{abstract}
RESUMO. Neste artigo, apontaremos os elementos de transforma(ação) pedagógica que o curso de Licenciatura em Educação do Campo provocou, nos últimos dez anos, na Educação Superior, na Universidade de Brasília. O curso é resultado de uma política pública efetivada a partir de uma experiência piloto implantada nessa Universidade. A pesquisa foi realizada tendo como epistemologia e método o materialismo histórico-dialético. A coleta de dados foi desenvolvida em duas etapas: na primeira, utilizou-se os instrumentos: questionários e a pesquisa documental para traçar o perfil dos egressos; e, na segunda fase, a pesquisa-ação e entrevistas, com estudantes que estavam cursando a pós-graduação, o que resultou no apontamento de elementos de transformação na materialização da realidade pedagógica que vai desde a alteração da estrutura física da universidade para atender os sujeitos camponeses até a epistemologia de trabalho adotada pelos egressos do curso.
\end{abstract}

Palavras-chave: Educação do Campo, Formação de Professores, Epistemologia da Práxis. 


\title{
Reflections about graduates of the Teaching Degree Course in Rural Education at the University of Brasília: elements for "Pedagogical (Action) Transformation" in Higher Education
}

\begin{abstract}
This paper addresses the elements of pedagogical (action) transformation brought about by the Teaching Degree Course in Rural Education, in the last ten years, in Higher Education at the University of Brasília. This course is the result of a public policy implemented based on a pilot program carried out in this University. The research was performed adopting historical-dialectical materialism as an epistemology and method. Data collection was developed in two steps: in the first step, the following instruments were used: questionnaires and documentary research to describe the profile of graduates; and, in the second stage, action research and interviews, with students who were attending postgraduate studies, which resulted in notes of transformation elements in the materialization of the pedagogical reality, ranging from changes in the university's physical structure to serve peasant subjects to the work epistemology adopted by graduates who took the course.
\end{abstract}

Keywords: Rural Education, Teacher Training, Praxis Epistemology. 


\section{Reflexiones acerca de los egresados de la carrera de Licenciatura en Educación del Campo de la Universidad de Brasilia: elementos para "Transformar (acción) Pedagógica" en la Educación Superior}

RESUMEN. En este artículo, señalaremos los elementos de transforma(acción) pedagógica que la carrera de Licenciatura en Educación del Campo ha producido, en los últimos diez años, en la Educación Superior, en la Universidad de Brasilia. Esta carrera es el resultado de una política pública efectivada a partir de una experiencia piloto implantada en dicha Universidad. Se hizo la investigación adoptándose como epistemología y método el materialismo histórico-dialéctico. La recolección de datos se desarrolló en dos etapas: en la primera etapa, se utilizaron los siguientes instrumentos: cuestionarios y la investigación documental para trazar el perfil de los egresados; y, en la segunda fase, la investigación-acción y entrevistas, con estudiantes que estaban cursando el posgrado, lo que resultó en el señalamiento de elementos de transformación en la materialización de la realidad pedagógica que va desde el cambio de la estructura física de la universidad para atender a los sujetos campesinos hasta la epistemología de trabajo adoptada por los egresados de la carrera.

Palabras clave: Educación del Campo, Formación del Maestros, Epistemología de la Praxis. 


\section{Introdução}

Consideramos necessário explicar com que sentido teórico utilizamos os termos que norteiam o título deste artigo: transformar significa, neste contexto, a modificação do estado das "coisas", sejam pautadas na materialidade ou nas relações sociais que estão inseridas; ação é o termo que se refere às mudanças concretas e/ou à realidade em movimento; pedagógica faz referência ao ambiente educativo, seja ele dentro ou fora da escola e/ou da universidade.

Essa compreensão pressupõe, portanto, modificações que estejam ligadas à ação de estudantes e professores, dentro e fora da sala de aula. Assim, a união das duas expressões sintáticas, "transformar (verbo) + ação (substantivo feminino)", cuja contração é marcada pelo parêntese, coloca-nos diante de ações que envolvem o "movimento da realidade educativa em movimento". O termo é cunhado a partir das análises metodológicas da pesquisa.

Consideramos desafiador analisar esse "movimento da realidade educativa" no curso de Licenciatura em Educação do Campo (LEdoC/UnB), um desafio pautado pela vivência no período da pesquisa (Brito, 2017) que nos possibilitou realizar experiências de inserção nas atividades do Núcleo de Estudos Básicos (NEB) e no estágio-docência.
Organizamos este artigo em dois eixos: no primeiro, apresentaremos a LEdoC/UnB e a defesa dos princípios da Educação do Campo e das suas concepções teóricas; no segundo, apresentaremos os principais elementos de transformação pedagógica detectados na pesquisa.

\section{O curso de Licenciatura em Educação do Campo da Universidade de Brasília nos seus primeiros 10 (dez) anos de implantação}

O curso de Licenciatura em Educação do Campo, da Universidade de Brasília, (Código INEP 112176), foi autorizado a funcionar, na modalidade presencial, no dia 27/08/2007, com carga horária total prevista de 3.525 horas/aula e 235 créditos, integralizados em 8 etapas (semestres) presenciais.

Com sede na Faculdade UnB de Planaltina, o curso é situado na Área Universitária 01, vila Nossa Senhora de Fátima, Planaltina - Brasília - Distrito Federal, autorizado pela Resolução número 38, de 10 de julho de 2007, e reconhecido pela Portaria $n^{\circ} 301$, de 08 de julho de 2016. O curso ofertou, nos últimos dez anos (2007-2017), 600 vagas. Desse total, foram ocupadas 90\% delas. Até 2017, cerca de 230 estudantes concluíram o curso, e há seis turmas em andamento. A maioria dos estudantes ainda se encontra em formação, o que nos mostra que a 
referida pesquisa aponta um estudo inicial no âmbito dessa política pública.

Constatamos baixa taxa de evasão frente às estatísticas nacionais dos cursos de Licenciatura em Educação do Campo. A baixa evasão na LEdoC/UnB se configura como um referencial positivo diante do cenário nacional da expansão dos cursos que, na atualidade, somam 42 experiências em funcionamento no Brasil. A nível nacional, das 5.000 mil vagas ofertadas, foram ocupadas 3.141, resultando em um índice de aproveitamento de apenas 63\%, o que, para Molina e Hage (2016, p. 805), é preocupante, pois,

... mesmo que as múltiplas estratégias de ingresso ao curso postas em prática sejam determinantes para a viabilização do acesso das populações camponesas à Educação Superior, elas ainda precisam ser aprimoradas com vistas ao fortalecimento e consolidação das Licenciaturas em Educação do Campo.

As perdas de vagas representam, no cenário nacional, um desafio a ser superado no âmbito da proposição do Programa de Apoio à Formação Superior em Licenciatura em Educação do Campo (Procampo), para maximização dos resultados dessa política pública imprescindível ao enfrentamento das imensas desigualdades educacionais existentes no meio rural brasileiro. (Molina, Montenegro \& Oliveira, 2009).
Uma vez que o investimento financeiro para esse programa gerou, inclusive, abertura de concursos públicos para a contratação de professores e funcionários administrativos efetivos, tal qual demandado na II Conferência Nacional por Uma Educação do Campo, faz-se necessária avaliação da repercussão dessa política pública. Consideramos que a baixa evasão na LEdoC/UnB se dá pelas ações criadas pela própria instituição para atender essa política pública, como a bolsa permanência $^{\mathrm{i}}$ e o alojamento ${ }^{\mathrm{ii}}$ tendo como intenção garantir a permanência dos sujeitos camponeses na universidade pública, como veremos nas próximas seções deste capítulo.

Molina (2015, p. 154) aponta como um dos desafios na expansão das Licenciaturas em Educação as "estratégias de ingresso de sujeitos camponeses" nessa nova modalidade de graduação, pois o curso foi criado no âmbito das políticas de ações afirmativas, o que demanda uma seleção diferenciada, sendo essa uma necessidade para viabilizar o acesso à educação superior a sujeitos que historicamente tiveram negados seus direitos pela omissão do Estado em garanti-los eficazmente.

O perfil do egresso aponta para três frentes de trabalho: a) docência em uma das áreas de conhecimento propostas pelo curso; b) gestão de processos educativos 
escolares e c) gestão de processos educativos nas comunidades (UnB, 2009). Nesta pesquisa, buscamos analisar a repercussão da formação, sobretudo com os egressos do curso que continuaram seus estudos no âmbito da pós-graduação lato e stricto sensu na perspectiva da Epistemologia da Práxis ${ }^{\text {iii }}$, analisando todas as frentes de atuação, desde a escolar até a participação desses estudantes nos Movimentos Sociais.

A maioria dos egressos da LEdoC/UnB está na Região Centro-Oeste, que possui uma área de $1.606 .403,5 \mathrm{~km}^{2} \mathrm{de}$ extensão territorial, com uma população de 15,3 milhões de habitantes (Pnad 2014 IBGE) e é crescente na produção do agronegócio. Segundo os dados da Associação Brasileira do Agronegócio (Abag), essa região é a maior produtora de cana de açúcar, soja, milho, pastagem, algodão herbáceo e arroz em casca. Além disso, destaca-se na criação de bovinos e suínos $^{\text {iv }}$. No mapa 1 , é possível verificar a distribuição dos egressos do curso em seus territórios de origem.

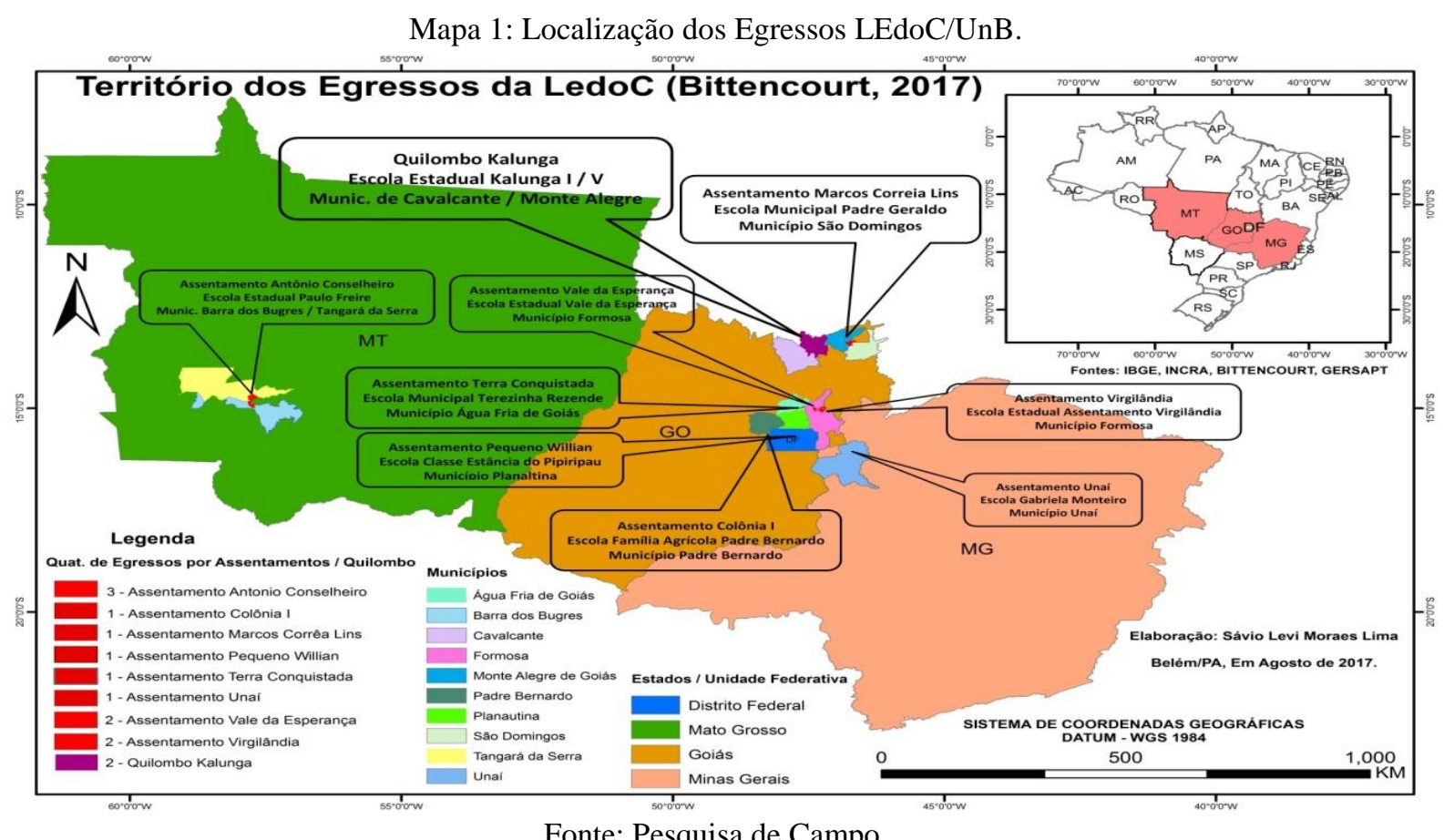

Fonte: Pesquisa de Campo.

A partir da análise de dados da pesquisa documental, realizada no sistema acadêmico, os 230 concluintes, até o ano de 2017, encontram-se em 18 municípios da Região Centro-Oeste: Formosa (GO),
Simolândia (GO), Nova Roma (GO), São Domingos (GO), Teresinha de Goiás (GO), Cavalcante (GO), Planaltina (DF/GO), São Bernardo (GO), Água Fria (GO), Ponta Porã (MS), Santo Antônio do Lavenger 
(MT), Barra dos Bugres (MT), Cárceres (MT), Tangará da Serra (MT), Nova Mutum (MT) e Sinop (MT), e em um munícipio da Região Sudeste, especificamente, no sudoeste mineiro: Unaí (MG). No mapa 1, é possível perceber ainda que os egressos do curso estão localizados em áreas de assentamento e de comunidades tradicionais, distantes da Universidade de Brasília, o que nos permite confirmar que o curso atendeu o objetivo inicial de formar sujeitos camponeses.

Um dos princípios do curso de LEdoC, demandado pelos sujeitos camponeses, é que atendesse à especificidade de trabalho e da vida no campo, e, para tal, objetivando não desenraizá-los de seus territórios, acontecesse em Alternância Pedagógicav: etapas presenciais (equivalentes a semestres de cursos regulares) em regime de alternância universitária, ou seja, Tempo/Espaço Universidade - Curso (denominado pela comunidade acadêmica do curso de TU) e Tempo/Espaço Comunidade - Escola do Campo (tendo sua denominação abreviada para TC). Esse modelo requer uma articulação intrínseca entre a educação e a realidade específica das populações do campo com seu território.
Segundo Santos (2012), que realizou pesquisa especificamente sobre a Pedagogia da Alternância na UnB,

$$
\begin{aligned}
& \text {.. a primeira experiência de } \\
& \text { formação por alternância no Brasil se } \\
& \text { deu no estado do Espírito Santo em } \\
& \text { 1969. As escolas receberam uma } \\
& \text { nomenclatura diferente da } \\
& \text { experiência francesa, e aqui, ficaram } \\
& \text { conhecidas como Escola Família } \\
& \text { Agrícola (EFA). (Santos, 2012, p. } \\
& \text { 54). }
\end{aligned}
$$

É importante destacar que essa experiência brasileira com a Pedagogia da Alternância sofreu a influência das escolas italianas e do sacerdote italiano Humberto Pietrogrande, que era missionário no estado do Espírito Santo. Um dos maiores objetivos da Pedagogia da Alternância é a formação integral dos sujeitos camponeses, ainda que sejam facilitados o acesso e a permanência no curso e na prática de sua formação nas Escolas do Campo. Essa forma de organização acadêmica fortaleceu a permanência dos jovens e adultos no campo, evitando, assim, reforçar a ideia de que o ingresso na educação superior implica deixar de viver no campo.

No curso de LEdoC, da UnB, consideramos a "Alternância Pedagógica" como um dos principais elementos de "transformar (ação) pedagógica", pois ela desencadeou uma série de modificações estruturais na universidade pública, como a possibilidade de permanência no 
alojamento construído na UnB, em que os estudantes têm a oportunidade de permanecer por aproximadamente 50 dias por período de TU, dentro do Campus. Após esse período, eles retornam para as suas casas e comunidades para atividades orientadas a serem desenvolvidas, tanto nas escolas como nas comunidades.

Com base nos resultados das entrevistas semiestruturadas e questionários, pode-se apontar um perfil para os egressos do curso de LEdoC:

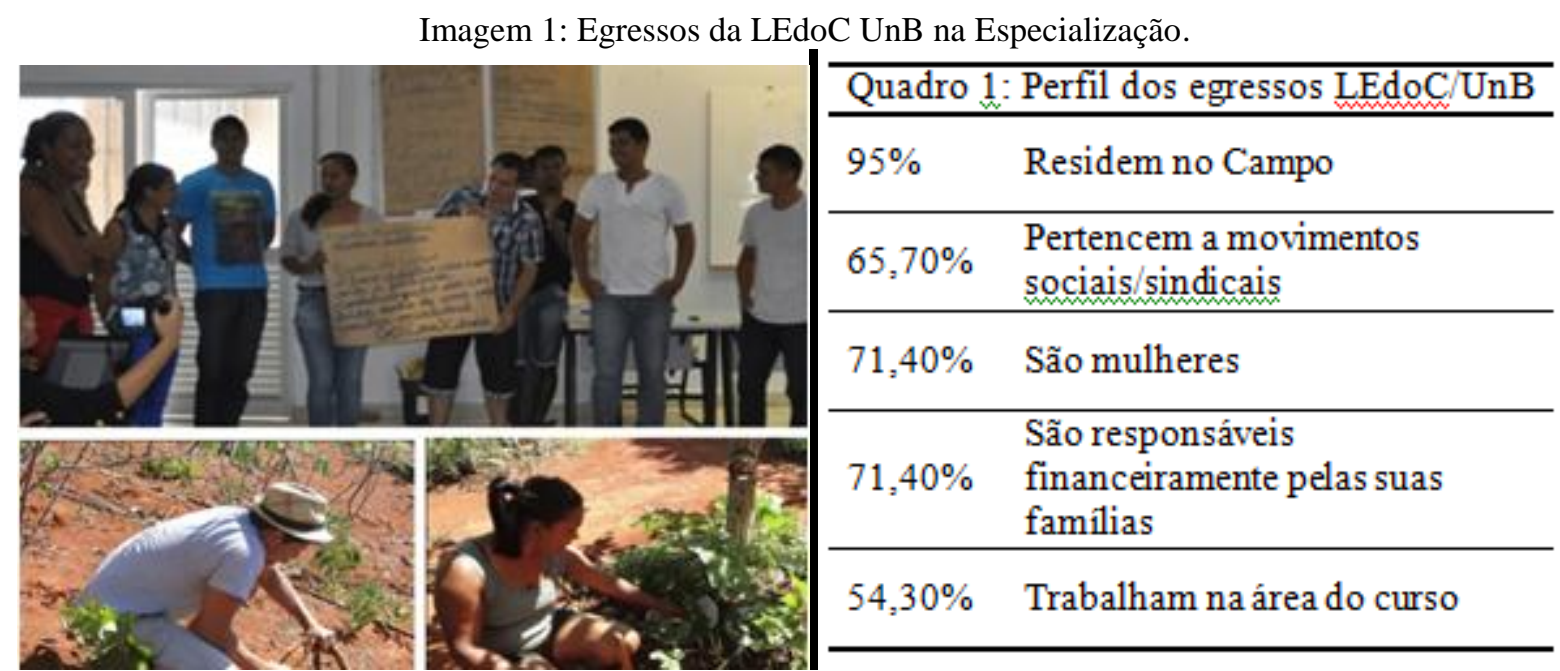

Fonte: Pesquisa de Campo.

Esse perfil permite-nos afirmar que os egressos do curso de LEdoC estão correspondendo ao perfil de formação apontado pelo projeto piloto do curso em relação à permanência em seu território e possibilidades de transformação na forma escolar. (Molina \& Sá, 2011; PPC, 2009). $\mathrm{O}$ fato de a maioria dos egressos ser mulheres, permanecer no campo, fazer parte de Movimentos Sociais/Sindicais e estar atuando na área do curso nos aponta que as transformações em vigor trazidas pela LEdoC na Educação Superior buscam, de fato, responder ao novo modelo de universidade exigida pelas lutas sociais, que esteja atenta às necessidades de formação dos sujeitos camponeses no Brasil na última década.

Ao contrário dessa perspectiva, a lógica tradicional de universidade brasileira - neoprofissional, heterônoma e competitiva (Sguissardi, 2014) que se sucede reforma após reforma no Brasil, ancorada basicamente por dois modelos: neo-humboldtiano e neonapoleônico - não prevê ações que visem à democratização do espaço universitário. No entanto o curso de LEdoC/UnB, a partir de ações contra hegemônicas, vem ocupando um espaço que visa a desenvolver uma formação democrática, crítica e emancipatória. (Molina, 2014). Obviamente, só é possível 
atingir um desafio de tal magnitude, rompendo com o modelo existente em várias dimensões. Dessa forma, na próxima seção, apontamos as principais transformações que o curso de LEdoC, segundo nossa percepção, vem realizando na Universidade de Brasília.

\section{Os principais elementos da "transformar (ação) pedagógica": resultados do estudo com egressos da LEdoC/UnB}

O presente estudo foi desenvolvido em duas fases: a primeira foi quantitativa, na qual demonstramos os resultados preliminares obtidos via questionário com 31 egressos. (Brito \& Molina, 2017). A pesquisa foi realizada de forma voluntária e por adesão e consistiu no envio do questionário para todos os egressos cadastrados na universidade, deixando-os livres para preenchimento. Consideramos que a dificuldade de acesso à internet não possibilitou a adesão da maioria. Já na segunda etapa, de caráter qualitativo, foi realizada a pesquisa-ação com 13 egressos que estavam cursando pós-graduação.

Constatamos que os egressos da LEdoC/UnB se formaram dentro de uma perspectiva epistemológica bastante diferenciada da formação docente hegemônica nas universidades brasileiras. A concepção orientadora dessa formação contra hegemônica funda-se na
Epistemologia da Práxis, que é um termo cunhado por Gramsci (1999) para se referir à dialética materialista de Marx, que nasce com o objetivo de superar o idealismo na medida em que agrega uma filosofia integral.

A formação dos professores nesse campo epistemológico busca estabelecer a relação entre a práxis e o conhecimento. Nessa questão, a perspectiva materialista histórica tem muito a contribuir para o campo pedagógico, principalmente no que tange à formação de professores, visto que sua fundamentação é rica em elementos críticos ao que se pensa da relação teoria e prática. (Silva, 2015).

A formação interdisciplinar se expressa nas várias disciplinas do Núcleo de Estudos Básicos, no Núcleo de Estudos Específicos e no Núcleo de Atividades Integradoras, bem como nos diferentes Tempos de Organicidade presentes no curso (Molina, 2014), além das místicas e das orientações para o TU e TC, o que tem conseguido promover uma formação crítica e emancipatória. Faz-se presente uma formação docente que tem seus fundamentos teóricos e práticos voltados para ampliar a compreensão dos educandos no sentido de promover a leitura crítica da realidade e oferecer-lhes os elementos necessários à promoção de intervenções coletivas para transformação da realidade, 
com ênfase em ações que objetivem avançar na direção do fortalecimento da Agricultura Camponesa voltada para práticas sustentáveis e saudáveis baseadas na Agroecologia.

Há uma repercussão direta da formação dos egressos da LEdoC/UnB nos diversos territórios da região centro-oeste, o que nos possibilitou compreender a práxis como categoria central para a construção do conhecimento e para afirmação de uma epistemologia (Noronha, 2010) como uma forma de mediação entre a universidade e o trabalho desenvolvido nas escolas de educação básica do campo.

Curado Silva (2011), ao desenvolver os princípios fundamentais para pensar a formação de professores com base nos pressupostos de uma educação críticoemancipatória, auxiliou-nos a tomar a realidade docente, em sua materialidade contraditória, nessa perspectiva na qual podemos pensar uma formação de professores para além da formação para a reprodução do capital. (Mészáros, 2008). Isso nos possibilitou investigar o trabalho docente dos egressos da LEdoC/UnB tomando a práxis, a função de ensinar e a pesquisa como princípios de formação e categorias fundantes no âmbito da formação de professores do campo.

Partindo dessas reflexões e pautandonos pelo trabalho desenvolvido no curso de
LEdoC/UnB, no período 2007 a 2017, a partir da pesquisa realizada com os egressos do curso, defendemos a tese de que a Educação do Campo apresenta, de fato, um projeto emancipador de formação de professores, construindo um novo paradigma educacional, pautado na Epistemologia da Práxis, portanto, carregado de mudanças e contradições.

Os egressos do curso de LEdoC/UnB incorporaram os princípios da proposição inicial realizada pelo Movimento da Educação do Campo, no processo de institucionalização do referido curso na Educação Superior Brasileira. Esses princípios vêm sendo desenvolvidos na Formação de Educadores do campo a partir da Matriz Pedagógica construída pelos sujeitos em ação nas escolas do campo, dos quais, destacamos como elemento de transformação pedagógica na universidade e na vida da comunidade e dos sujeitos envolvidos:

a) $\quad$ modelo de produção e desenvolvimento do País para o qual o curso se assenta, ou seja, a agroecologia: o currículo do curso aponta,, de forma articulada, a formação de professores para o campo, considerando a Reforma Agrária, a Agroecologia, a Soberania Alimentar como eixos articuladores do currículo, sendo que os professores formadores da LEdoC buscam planejar os componentes 
curriculares e as etapas do curso relacionando-os com as vivências práticas dos educandos em suas comunidades e territórios;

\section{b) Alternância Pedagógica:}

essa relação de conteúdos com a realidade que inicia através de Planejamento Coletivo dos professores da LEdoC pois enfatiza “... colocar a realidade como centro em torno dos quais as ciências e outras formas de conhecimento se articulam, para que a realidade possa ser não apenas compreendida e analisada, mas também transformada". (Molina \& Sá, 2011, p. 43).

Consideramos que o trabalho docente dos professores-formadores centra-se no princípio da práxis pedagógica, em um processo que articula o movimento de teoria e prática no conhecimento da realidade. Para Queiroz (2004), a Alternância não é somente uma forma de revezar a formação entre espaços diferentes, em virtude do modelo produtivo ou das necessidades de trabalho dos estudantes e de suas famílias. Ela tem uma organização teórica e prática que deve ser incorporada aos cursos que a adotam como opção organizativa, pois, para que seja realizada, ela deverá se pautar em alguns instrumentos na sua constituição: plano de formação; plano de estudo, que estão organizados pelos critérios abaixo:
1. Colocação em comum: socialização e organização dos conhecimentos da realidade dos estudantes do seu meio, que servem de base para o aprofundamento articulado nas várias áreas do saber, com ênfase para a interdisciplinaridade;

2. Visitas de estudo;

3. Intervenções externas palestras, seminários, debates, experiências;

4. Visitas à família do aluno;

5. Caderno de acompanhamento da Alternância e avaliação - contínua e permanente.

Pode-se perceber que há um longo processo de construção que deve ser protagonizado pelos professores e educandos na Educação do Campo em relação à Alternância. Isso materializa-se, sobretudo, quando tal educação é oferecida na Educação Superior, uma vez que a Alternância demanda dos professores do curso uma tarefa de acompanhamento individual e coletivo dos estudantes e um modelo de avaliação contínua, processual, dinâmica e permanente.

c) alojamento de estudantes dentro da universidade pública - transformação na estrutura física: para atender os sujeitos camponeses, provenientes de outros estados e assentamentos e comunidade 
distantes, conforme demonstramos no Mapa 1. A partir de muita mobilização e organização, a gestão universitária, comprometida com o curso de LEdoC/UnB, de posse da sua autonomia universitária e com recursos demandados para esse fim na gestão dos presidentes Luiz Inácio Lula da Silva e Dilma Rousseff (2003-2013), construiu o alojamento D. Tomas Balduíno, na Faculdade UnB Planaltina, com uso prioritário para os estudantes do curso de LEdoC. Inaugurado em 2015, o alojamento possui dormitórios coletivos que abrigam, no máximo, 10 estudantes em cada, com capacidade total para 100 estudantes. $\mathrm{Na}$ área externa, os estudantes têm tanques para realizar o trabalho de lavagem de roupa, área de convivência e espaço de funcionamento para ciranda infantil, que trataremos mais adiante. Essas áreas são de uso coletivo durante o período em que estão na universidade.

\section{d) A Organicidade e} Trabalho Coletivo dos educandos e educadores da LEdoC: a organicidade é uma atividade da rotina diária, no período em que os estudantes estão na UnB para cursar as disciplinas (Tempo Universidade). Ela possui um conjunto de atribuições que envolvem todos os estudantes em atividades de grupo para resolução dos problemas. Em suma, “... é uma forma de auto-organização dos educandos, e busca assegurar que coletivamente possam discutir as questões que lhe dizem respeito enquanto educando, ser humano e sujeito social construindo-se como sujeitos autônomos e responsáveis pela condução dos seus processos formativos". (Araujo, 2014, p. 43).

Ao contrário da formação para o "mercado de trabalho" capitalista, na qual cada indivíduo é responsável pelo seu sucesso e busca qualificação profissional para competir junto aos outros indivíduos, pois tem a certeza de que quem obtiver o melhor currículo e as melhores oportunidades será beneficiado no sistema de mérito, a formação para emancipação humana busca o desenvolvimento integral do ser humano. A organicidade se divide em:

\section{O trabalho coletivo como} princípio de formação é indispensável para a transformação da forma escolar tão almejada pela Educação do Campo, pois ele é a "força motriz na produção de conhecimentos sobre a realidade social e para enfrentamento do contexto pedagógico/formativo e do trabalho docente na Escola do Campo e na universidade". (Ferreira, 2015, p. 214).

No curso de LEdoC/UnB, essa é a força motriz dos educandos e educadores. Dos egressos pesquisados, $73 \%$ 
responderam que é por meio do trabalho coletivo que eles estão conseguindo modificar seu trabalho docente.

2. A ciranda infantil aparece em todas as falas das egressas-mães como um espaço necessário para a permanência delas nos longos períodos do TU, já que uma das maiores dificuldades por elas encontradas é conciliar o trabalho, o estudo e o cuidado com os filhos. O trabalho na ciranda envolve três atividades diárias mínimas:

a) Cuidado com as crianças: participar das atividades da ciranda, tanto no cuidado das crianças quanto na elaboração de atividades pedagógicas;

b) Limpeza dos brinquedos: garante a limpeza dos brinquedos utilizados pelas crianças, uma vez ao dia;

c) Limpeza da Ciranda: garante a higiene do espaço da Ciranda. Faz escala para auxiliar as mães fora do horário de aula (manhã, meio dia e noite).

A ciranda infantil é um espaço que não tem como separar do TU, na Alternância, pois o bom funcionamento do curso depende dela. $\mathrm{O}$ espaço para ciranda infantil na LEdoC/UnB é inspirado nas cirandas infantis, a partir da experiência do Movimento dos Trabalhadores Rurais Sem-Terra.

A primeira Ciranda Infantil Nacional aconteceu em 1997, no Encontro Nacional dos Educadores e das Educadoras da Reforma Agrária, com 80 crianças de todo o País. No ano de 2000, durante o IV Congresso Nacional do MST, participaram 320 crianças da Ciranda Infantil Itinerante, e o encontro tornou-se um marco de referência para a organização das cirandas. (Luedke, 2013).

No Movimento dos Trabalhadores Rurais Sem Terra, a proposta é "Criar um espaço educativo para os filhos e filhas das famílias que participam do MST". (MST, 2004, p. 39). Também organizadas em Tempos Educativos, as cirandas são espaços de respeito à infância, no seu tempo, considerando fundamentalmente que a organização da vida humana é formativa e não pode deixar de proporcionar uma formação social. Luedke (2013), ao pesquisar a experiência do MST e a ciranda, define os tempos como:

Tempo Acolhida deve ser realizado com a chegada das crianças, por meio de uma música ou de uma brincadeira diferente que torne $\mathrm{o}$ ambiente acolhedor para recebê-las. Tempo Linguagens integram atividades que envolvam diferentes linguagens, entre elas as artes plásticas, o teatro, a música, a dança, as histórias e as brincadeiras. Tempo do Brinquedo pode ser livre ou orientado, a fim de propiciar a relação da criança com o mundo e estabelecer a socialização entre crianças e crianças, crianças e adultos. Tempo do Descanso proporciona ambiente calmo e tranquilo para o descanso que é necessário para as crianças e os seus 
ritmos. Tempo da Alimentação incentiva desde a autonomia de as crianças comerem sozinhas, até o reconhecimento de uma alimentação saudável. Tempo da Higiene está presente em todas as situações diárias, antes das refeições, no escovar os dentes, no banho, depois das brincadeiras, na troca de fraldas. Tempo Coletivo dos Educadores é exclusivo aos educadores, pode ser diário ou semanal, para avaliação, planejamento e troca de experiências. (MST, 2010b apud Luedke, 2013, p. 103).

Esses tempos formativos devem ser respeitados de acordo com as etapas de desenvolvimento da infância. A Ciranda Infantil do curso de LEdoC/UnB é o espaço que recebe as crianças, filhos(as) das estudantes do curso, a partir dos nove meses de idade, e tem como principal objetivo o cuidado e a formação, enquanto as mães estão em atividades de formação docente.

$\mathrm{Na}$ LEdoC/UnB, a ciranda vem sendo construída junto com a regulamentação do curso e, na atualidade, já conta com espaço físico definido dentro do alojamento. Desde a criação da LEdoC, a ciranda busca ser um espaço no qual os(as) filhos(as) das estudantes possam permanecer e se desenvolver, não somente com cuidados, tampouco como depósito de crianças, mas, também, com atividades que ajudem no desenvolvimento das crianças. Assim, esse espaço faz parte de um momento fundamental da vida das mães: o de conquista do direito à educação e à profissionalização.
Santos (2015), egressa do curso de LEdoC, apresentou seu trabalho de TCC intitulado "Ciranda Infantil e a Formação de Educadores do Campo: a experiência da UnB Planaltina" em que apresenta a Ciranda Infantil na LEdoC como um espaço de desenvolvimento das crianças.

e) A repercussão na formação na perspectiva da Epistemologia da Práxis: Conforme o perfil exigido para formação inicial do licenciado em Educação do Campo pela UnB, constatou-se que a formação para a Docência multidisciplinar proveniente da formação por área de conhecimento apontou transformação na prática desses professores em suas comunidades.

Constatamos que a maioria dos egressos do curso da LEdoC/UnB estão atuando em uma ou mais das três frentes de formação previstas no currículo do curso, em que se percebe o perfil do profissional a se formar. São elas as três frentes de formação:

- Docência em uma das áreas de conhecimento propostas pelo curso: Linguagens; Ciências da Natureza e Matemática. A proposta é de que cada uma das turmas ofereça aos estudantes a opção de escolha em duas dessas áreas, sendo essa definição construída entre a Universidade e suas parcerias 
considerando as demandas/perfil do grupo e as condições objetivas da oferta.

- Gestão de processos educativos escolares: entendida como formação para a educação dos sujeitos das diferentes etapas e modalidades da Educação Básica, para a construção do projeto políticopedagógico e para a organização do trabalho escolar e pedagógico nas Escolas do Campo. Ênfases: Educação Fundamental Anos Finais e Educação Básica de Nível Médio, também na Modalidade Educação de Jovens e Adultos e na combinação com a Educação Profissional.

- Gestão de processos educativos nas comunidades: preparação específica para o trabalho formativo e organizativo com as famílias e ou grupos sociais de origem dos estudantes, para liderança de equipes e para a implementação de iniciativas e ou projetos de desenvolvimento comunitário sustentável que incluam a participação da escola. (UnB, 2009, p. 18. Grifos nossos).

Constatamos ainda que os egressos que estão na docência em uma das áreas de conhecimento propostas pelo curso ministram várias disciplinas dentro da área, dependendo da etapa de atuação: nos anos finais do Ensino Fundamental e no Ensino Médio, ministrando as seguintes disciplinas:
- Ciências;

- Biologia;

- Matemática;

- Física;

- Química;

- Língua Portuguesa;

- Leitura e Oralidade;

- Espanhol;

- Geografia;

- Filosofia;

- Sociologia.

Destaca-se que muitos descreveram ainda que estão na atuando na UniDocência.

Apesar da formação não ser direcionada para as séries iniciais do ensino fundamental, a necessidade de professores no campo levou os egressos a ocupar essa função nos anos iniciais do ensino fundamental, e, por sua vez, estão ministrando as disciplinas de:

- Língua portuguesa;

- Práticas quilombolas.

Ao detectarmos as disciplinas que os egressos do curso trabalham, percebemos que, além da daquelas específicas de sua área de atuação, seja em Linguagem ou Ciências Naturais, eles estão ministrando disciplinas inovadoras voltadas para a realidade das Escolas do Campo, como nos casos já citados de Práticas Quilombolas e Ciências Agrárias. 
Uma das frentes de formação descrita no Projeto Pedagógico do Curso e que nos apontou muitas reflexões em torno da formação desses professores foi a formação para atuar na gestão de processos educativos nas comunidades. Para perceber a inserção dos egressos nessa frente de formação, questionamos se esses sujeitos participavam de algum Movimento Sindical e/ou Social, ao que $65,7 \%$ egressos responderam positivamente, confirmada pelo gráfico 1 , no início desse texto e confirmada através do vínculo deles com:

- Movimento dos Trabalhadores Rurais sem Terra (MST);

- Movimento de Apoio ao Trabalhador Rural (MATR);

- Sindicato dos Trabalhadores em Educação de Goiás (Sintego);

- Movimento da Educação do Campo;

- Associação de Educação;

- Povo, Terra e Campo (Epotecampo) $^{\mathrm{vi}}$;

- Federação Nacional dos

Trabalhadores e Trabalhadoras na Agricultura Familiar (Fetraf);

- Sindicato dos Trabalhadores da Agricultura Familiar de Formosa (SintrafFormosa);

- Associação de Produtores Rurais;
- Sindicato dos Trabalhadores Rurais (STR);

- Federação dos Trabalhadores na Agricultura do DF e Entorno (Fetadef);

- Movimento de Luta pela Terra (MLT).

Além desses movimentos, identificamos, através da pesquisa, outras frentes de produção e organização econômica e social, construídas a partir dos egressos do curso de LEdoC/UnB:

- Tuya Kalunga - marca de roupas com identidade quilombola, criada por uma das egressas do curso, a partir da consciência identitária conquistada durante o processo, segundo nos afirmou a referida egressa;

- Grupo de teatro Quebrando as Correntes (reúne egressos e educandos da LEdoC e do Residência Agrária Jovem);

- Associação Quilombo Kalunga de Cavalcante (egressos como membros da diretoria);

- Egressos na direção e coordenação pedagógica da escola do Engenho II;

- Grupo de Rap Ant'Cistema;

- Comuna Feminista Panteras Negras.

Esse protagonismo repercutiu no discurso e na prática social dos egressos quando questionados "Licenciados em Educação do Campo e agora?" 
E agora? Tentar um concurso público. Não dá para se comparar. Prestar um concurso público, passar no concurso público. Ir para uma Escola do Campo e fazer meu trabalho lá. (Xavier, 2016, informação verbal).

$\mathrm{O}$ anseio maior, né, posterior à formatura, é de atuar imediatamente. E a minha atuação nunca se limitou apenas à sala de aula, eu tive que aguardar um período para ir para a sala de aula. Mas eu fui dando continuidade na organização tanto da comunidade como contribuindo na própria escola. $E$ o anseio maior era de transformar a escola. E não era qualquer escola. Era a escola da minha comunidade. A escola que minhas filhas estudavam, a escola que nós fizemos luta pra conseguir, estamos em processo de luta pra não deixar ela fechar. Então, era essa escola, né, que pertence à nossa comunidade, que pertence a um território que vimos com um processo de luta, com uma gestão que mudou o trabalho e foi interrompido. Então, me voltei para a comunidade. Então, não terminou em momento algum esse anseio, porque acabou que faz parte da minha vida. Faz parte da minha graduação essa obsessão de transformar a escola. E não só isso. Dar minha contribuição nesse processo de formação do próprio curso de licenciatura. Não em uma disciplina, que eu nunca pensei em disciplina. Mas, na organização dos estudantes. Que outros ensinamentos como mística, organicidade, são necessários para se formar como educador do campo? Que eu tive isso desde a minha militância dentro do movimento, e eu vinha percebendo que o público ia modificando, e isso faz parte da formação. Então, na medida em que eu pude colaborar com a minha experiência de movimento, com a minha experiência da Licenciatura em Educação do Campo, dentro das turmas da licenciatura que estão e que já se formaram. Daí eu procurei... até conseguir estar em sala de aula, não em qualquer sala de aula. Mas na sala de aula da Escola do Campo. Porque eu já tive oportunidade de dar aula na cidade e em escola particular. Eu tive. Mas não estaria satisfeita e não ia me completar. $E$ as pessoas até me perguntaram: você está estudando para voltar pra roça? $\mathrm{E}$ falava: Estou estudando para voltar e mudar tanto a escola que eu moro como a comunidade que eu moro. Não sozinha, mas, no coletivo. (Santos, 2016, informação verbal).

Novos desafios na nossa vida. A gente agora é formado em Licenciatura em Educação do Campo, uma formação diferenciada das demais, onde a gente trabalhou muito a nossa comunidade. Então, além da nossa docência em sala de aula, como era antes, a gente tem que trabalhar com o educando, como ele vem... A gente não pode esquecer da realidade dele. $E$ sempre trabalhar em coletivo porque nossa formação é essa, trabalhar em coletivo. Pra mim, particularmente, foi um aprendizado muito grande trabalhar em coletivo, porque eu era muito individualista, antes de chegar na licenciatura, e isso pra mim foi um dos principais elementos da minha vida mesmo, foi o trabalhar no coletivo. (Souza, 2016, informação verbal).

E agora, né? Aumenta o compromisso, porque não é só a condição de estar licenciado de um diploma, mas um compromisso social, de sujeito, de ser humano, de vida, responsabilidade de vida. Porque antes eu pensava assim: eu preciso licenciar para poder melhorar a minha relação no trabalho para a questão financeira, de estabilizar, ter emprego. $\mathbf{E}$ 
LEdoC passa ter um peso diferenciado, não é uma licenciatura qualquer, é uma licenciatura para a vida. $\mathbf{E}$ a formação do sujeito para a vida, independente de um de diploma, de um certificado. É atuação na sua ação, na sua prática, que vai ter toda uma reação para o futuro. (Santos, 2016, informação verbal).

Agora tentar desenvolver na escola e na comunidade aquilo que a gente aprendeu no curso. Acho que foi uma formação muito boa, no sentido da Educação do Campo, daquilo que a gente aprendeu na escola trabalhar o coletivo, e acho que foi muito bom. Agora, a gente tem que desenvolver na escola e não parar aqui. Tem que estar sempre estudando. Isso não parou aqui, não terminou com a formação. Mas, é estar sempre se reunindo, sempre estudando, sempre avaliando e fazer tudo de forma coletiva, porque o mais importante na LEdoC é essa questão que a gente não pode fazer sozinho, tem que ser no coletivo. (Souza, 2016, informação verbal).

Os egressos sujeitos desta pesquisa apresentaram expectativas que vão desde a vontade de trabalhar no campo, na busca pela transformação da realidade dos educandos, até a formação continuada e permanente que deverá ser pautada pelos estudos de pós-graduação na universidade.

Suas aspirações são baseadas no trabalho coletivo, princípio que rompe com a formação capitalista e excludente das escolas brasileiras. Uma das necessidades apontadas, e que vale destacar, é a formação humana e o desejo de superação do atual modelo de escola pública tradicional ainda hegemônica no Brasil. Permanecer no campo e transformar a escola coletivamente são princípios que saem dos projetos em papel e se torna a prática dos egressos. $\mathrm{O}$ trabalho docente nessa perspectiva é, portanto, a mediação entre o meio educativo (Freitas, 2010), ou seja, o território e a realidade dos educandos e a sistematização de saberes e conhecimentos científicos que possam dar sustentação para compreender e transformar a realidade e a vida dos camponeses e alcançar os objetivos e o êxito na superação da fragmentação do conhecimento.

Tanto o coletivo de educadores da LEdoC/UnB como os coletivos da escola, conforme analisado na pesquisa-ação, apontam que é possível verificar o conhecimento partindo da sua compreensão e possibilidades em torno da teoria e perceber avanços, transformações e rupturas. A Escola Estadual Vale da Esperança passou por profundas transformações desde sua criação. Nos registros abaixo, é possível visualizar um pouco desse cenário. 


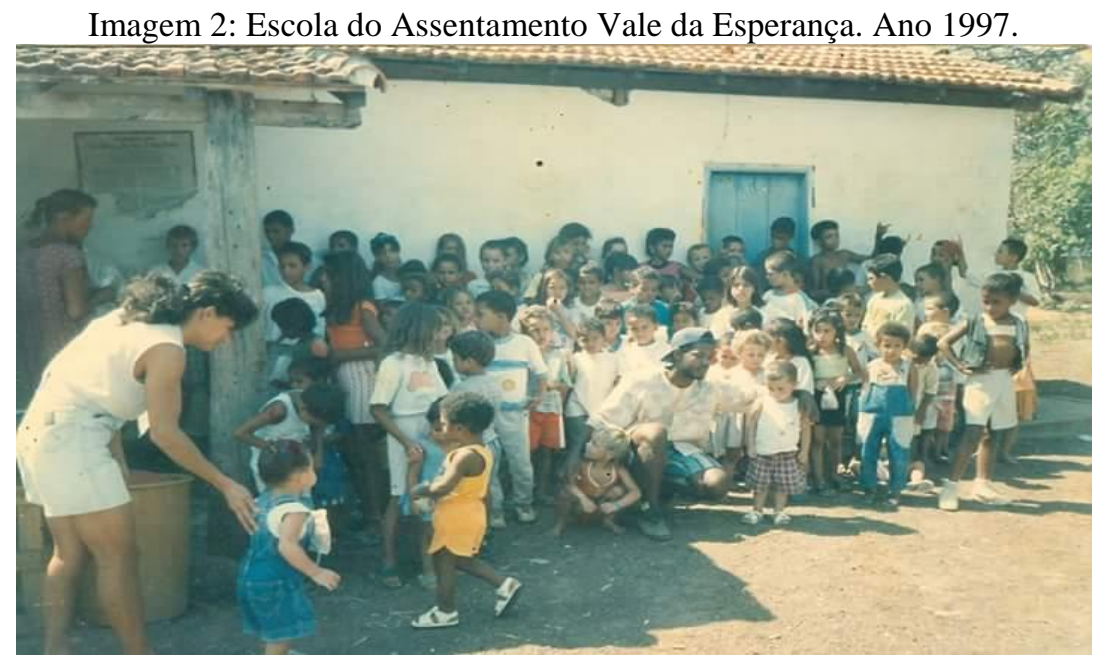

Fonte: Escola Estadual Vale da Esperança, 1997 (Acervo da Escola).

Imagem 3: Escola do Assentamento Vale da Esperança.

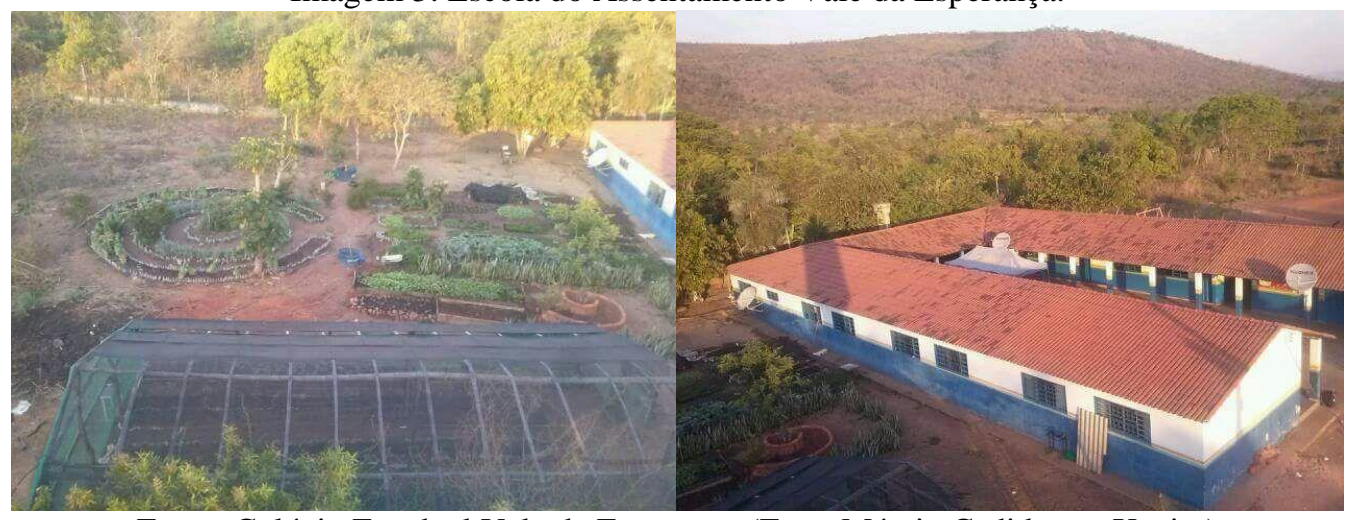

Fonte: Colégio Estadual Vale da Esperança (Foto: Márcio Cedida por Xavier)

Obviamente, as alterações na estrutura física da escola, sobretudo, na área externa, da "Mandala" e do "viveiro", apontam que o "Trabalho" cultivado na Escola Estadual Vale da Esperança pautase nos princípios da Educação do Campo. Constatamos que a transformação da forma escolar realizada pelos egressos da LEdoC está entrelaçada de certezas e afirmações em torno da formação inicial e continuada dos educadores.

O discurso e prática social dos egressos da LEdoC partem da mesma singularidade que Xavier (2016, p. 106) apontou com sua pesquisa de mestrado de que

... é possível transformar a forma escolar, saindo de escola rural para uma escola do campo. Mostrou que, para que isso possa acontecer, necessita de uma aproximação com a comunidade e com os movimentos sociais do campo, precisa ainda de uma formação docente com ênfase em Educação do Campo, seja na graduação ou formação continuada de professores. Não se pode pensar na escola do campo, sem o campo, sem sua cultura, sem sua produção e sem pessoas engajada nesse movimento. Conclui-se que a luta pela educação no Assentamento Vale da Esperança, teve em sua materialidade, em certos momentos um avanço e em outros um 
retrocesso. É nessa dialética que a história foi se formando, mostrando assim, para a comunidade e para esses sujeitos que é possível continuar lutando por uma escola que seja para atender as necessidades e os interesses do camponês.

Quando questionamos o egresso, pesquisador, ex-diretor da escola que realizou sua formação inicial e continuada na LEdoC/UnB sobre a viabilidade da transformação, ele afirmou como se deu o processo dessa transformação:

Então, algum tempo atrás, lá no Vale da Esperança. A gente conseguiu ter autonomia junto com o coletivo de educadores. A gente conseguiu mudar o currículo da escola. A gente colocou o pé no barranco mesmo. A gente não aceitou o "caderno educacional". (Pedro, 22 de novembro de 2016, informação verbal).

O caderno educacional é a proposta da Secretária de Educação do Estado de Goiás para as Escolas do Campo, que, na maioria das vezes, é descontextualizado e segue padrões de exigência voltados para avaliação em larga escala pautado na padronização curricular. Lamosa (2014) mostrou, a partir dos estudos nas escolas do campo em Ribeirão Preto/SP, como o agronegócio tem elaborado "cartilhas" que apontam e "ajudam" a influenciar o discurso e a prática desse modelo de produção.
Desse modo, formar os professores da escola do campo para resistência tem um viés ideológico que busca não somente se contrapor ao modelo hegemônico educacional vigente no Brasil, mas, sobretudo, refazer, com base na prática, no trabalho dos camponeses, o caminho para que a ciência seja realmente utilizada para a construção de tecnologias sociais que visem à melhoria de vida das pessoas.

Xavier (2016, p. 7. Grifos nossos) resume sua pesquisa mostrando,

... a compreensão dos dois modelos de desenvolvimento agrário em disputa no campo brasileiro. Assim, podemos compreender a Educação do Campo e seus espaços de lutas e conquistas, a escola é um dos espaços de lutas e assim precisa ter uma escola articulada com a vida do camponês. Para pensar na Educação do Campo é preciso lutar por políticas públicas e superar os velhos paradigmas. A Licenciatura em Educação do Campo é uma política pública construída e consolidada pelo movimento da Educação do Campo, que pensa na formação de educadores e educadoras na perspectiva emancipadora. No percurso da organização dos conteúdos coletados, podemos destacar as seguintes categorias: o trabalho como princípio educativo, auto-organização dos estudantes, trabalho coletivo, interdisciplinaridade e uma escola do campo ligada com a vida dos estudantes. $\mathrm{O}$ resultado da pesquisa nos leva a compreender que as matrizes formativas da Educação do Campo se fazem necessárias na escola do campo. Uma escola que deve ser pensada pelos trabalhadores do campo para os trabalhadores do campo. Podemos destacar ainda que 
no período pesquisado, no período que a comunidade estava inserida de alguma forma na escola, a proposta da Educação do Campo era cultivada, e o coletivo (comunidade e escola) trabalhava em prol da Educação voltada para o povo camponês.

A afirmação que o pesquisador apresenta em relação à consolidação da política pública da Educação do Campo na perspectiva emancipadora nos levou a questioná-lo sobre como ele vê o professor nesse processo, o qual nos respondeu:

Como uma ferramenta para isso, a educação não está somente na escola, né? Todas as relações se formam o tempo todo com a relação familiar e o professor é uma parte dessa relação. A docência é uma parte. Não é o todo. Não é o fim. Eu vejo a docência como uma profissão belíssima que tem o seu papel fundamental na sociedade. $E$ que precisa fazer seu papel. (Xavier, 22 de novembro de 2016, informação verbal).

A compreensão do egresso da LEdoC em torno da docência nos aponta que um dos caminhos para transformação da forma escolar defendido pelo Movimento por Uma Educação do Campo deve iniciar a partir do acesso dos camponeses às universidades e de sua formação em vários aspectos do desenvolvimento humano.

A formação docente na perspectiva emancipadora não é apenas uma opção contra hegemônica, mas a necessária formação para transformação social reconhecida até o momento pelos camponeses que se colocaram em "Marcha" pela ocupação dos latifúndios de terra e do saber.

Os egressos do curso de LEdoC vêm protagonizando modificações na realidade brasileira a partir do local em que pisam. $\mathrm{Na}$ próxima seção, apontamos algumas dessas repercussões nas escolas de Educação Básica da região pesquisada.

f) Criação de uma nova matriz de organização da Escola do Campo: Os egressos do curso de LEdoC/UnB apontam em nossas pesquisas uma nova forma de organizar o trabalho pedagógico nas escolas do campo. Não podemos perder de vista que o esforço de constituir uma Matriz para o Curso de Licenciatura em Educação do Campo é coletivo e foi pensado a partir da parceria com o Instituto Técnico de Educação Josué de Castro (ITERRA), que, no Estado do Rio Grande do Sul, aprofundou-se nos "caminhos para transformação escolar" baseado nos complexos de Pistrak.

Tomados pelo mesmo princípio orientador da licenciatura, analisamos a prática social dos egressos da LEdoC/UnB com o fundamento "de permanecer sempre no solo da história real; não de explicar a práxis a partir das ideias, mas de explicar as formas ideológicas a partir da práxis material” (Marx, 1991, p. 56). E essa 
forma real nos revelou que, nos diferentes territórios pesquisados, a matriz formativa tem repercutido, com intensidade significativa, de formas bastante diferenciadas a partir, inclusive, da formação inicial e continuada que os egressos do curso têm conseguido fazer.

Nossas análises se deram em duas escolas, nas quais conseguimos visualizar essas repercussões: a Escola Estadual Vale da Esperança (Estado de Goiás) e Escola Estadual Ernesto Che Guevara (Estado de Mato Grosso). Nos resultados das pesquisas, ambas são escolas de assentamentos que têm buscado promover um esforço de avançar em direção ao modelo de produção da agroecologia em contraposição à lógica do capital e, que, portanto, buscam também organizar o trabalho pedagógico das escolas localizadas dentro deles em contraposição ao modelo escolar hegemônico, no qual a escola está desconectada das questões e desafios da comunidade em que está inserida. Superar essa condição implica promover profundas transformações na forma escolar, buscando alterar a lógica da Organização do Trabalho Pedagógico, especialmente no que diz respeito aos modos de produção do conhecimento e às relações sociais que se desenvolvem a partir da escola. (Freitas, 2006).
O discurso e a prática social dos egressos do Curso de LEdoC reafirmam essa relação e apresentam o envolvimento e o compromisso desses sujeitos camponeses, não somente com uma formação inicial voltada para a educação, mas com as práticas sociais que garantam a sobrevivência em seus territórios. Vejamos o que afirma este egresso em sua dissertação de mestrado:

\begin{abstract}
A Agroecologia trabalha não somente com agricultura meramente cultivada, mas com a vida dos agentes envolvidos. Por exemplo, numa comunidade onde se tem como princípio produtivo a Agroecologia, existe uma valorização da cultura, dos saberes, das técnicas milenares tradicionalmente valorizadas pelas comunidades, coexistindo assim o homem com a natureza, sempre com respeito. Numa prática agroecológica, diferentemente do agronegócio, não se utiliza "venenos" nem se produz monocultivamente, as práticas são de utilização da natureza para os insumos orgânicos, uso do policultivo, respeitando as festas tradicionais e o modo de ver e viver a vida. (Xavier, 2016, p. 32).
\end{abstract}

Esse egresso defende que a produção agroecológica não está ligada somente à alimentação, mas ao modo de vida camponês e ao seu conhecimento da realidade e de sua ação partícipe na natureza, o que faz do camponês um conhecedor de seu território. Desse modo, destacamos a matriz formativa criada a partir do trabalho pedagógico desses egressos. 
$\mathrm{Na}$ Escola Estadual Ernesto Che Guevara, localizada no Assentamento Antônio Conselheiro, foram realizadas transformações em várias dimensões: no projeto pedagógico do curso, na formação dos professores que trabalham na escola e na forma de ensinar o conteúdo, a partir do trabalho dos egressos da LEdoC, que também cursaram na UnB, a Especialização para o Trabalho Docente Interdisciplinar em Ciências da Natureza e Matemáticas nas Escolas do Campo.

\section{O Assentamento Antônio} Conselheiro, localizado no município de Tangará da Serra, estado de Mato Grosso, iniciou suas atividades há 21 anos com a conquista da terra em 1996. A história da comunidade local é marcada por um acidente nessa ocupação que levou à morte 5 acampados e deixou uma marca de tristeza para as famílias e de luta para todos, uma vez que, como eles, muitos acampamentos e assentamentos têm a marca de sangue dos camponeses para a permanência em seus territórios.

Segundo o professor Claudio José Alves ${ }^{\text {vii }}$, liderança do assentamento e professor pedagogo da Escola Ernesto Che Guevara, o assentamento faz parte de três municípios (Tangará da Serra, Barra do Bugre e Nova Olímpia); são 37 mil hectares de terra. Para os pesquisadores Lazaroto, Anoch e Rosa (2010) $)^{\text {viii }, ~ o ~}$ referido assentamento é um dos maiores da América Latina, com 63 Agrovilas.

A comunidade escolar vem realizando um trabalho de transformação na forma escolar, o coletivo de educadores da escola tomou a decisão pela reorientação curricular com o objetivo de aprender a trabalhar o currículo por área de conhecimento, a repercussão desse trabalho foi organizada por Molina (2017) no livro "Licenciatura em Educação do Campo e o ensino de Ciências Naturais: Desafios à promoção do trabalho docente interdisciplinar" que apresenta os desafios à promoção do trabalho docente interdisciplinar.

Já na Escola Vale da Esperança os pesquisadores Machado (2014), Lima (2015) e Xavier (2016) apontam as transformações, rupturas e retrocessos na repercussão da transformação da forma escolar no contexto da Educação do Campo, ocorrido nesse território, imerso em intensas disputas. Xavier (2016, p. 111), egresso da LEdoC, mostrou-nos que “é possível transformar a forma escolar, saindo de escola rural para uma escola do campo, mas para que isso possa acontecer, necessita de uma aproximação com a comunidade e com os movimentos sociais do campo". Esse processo de transformação foi realizado tomando como base a formação inicial dos professores e a 
participação efetiva do curso através da Matriz Formativa e Organização do Trabalho Pedagógico apreendido a partir da formação realizada pelo Curso de LEdoC.

O curso tinha por objetivo em seu projeto curricular formar educadores do campo tomando como referência os Complexos de Estudo (Pistrak, 2009), que são

... uma tentativa de superar o conteúdo verbalista da escola clássica, a partir do olhar do materialismo históricodialético, rompendo com a visão dicotômica entre teoria e prática (o que se obtém a partir da centralidade do trabalho socialmente útil no complexo). (Freitas, 2010, p. 9).
Não é um método e sim a própria vida, que tem no trabalho, a mediação entre a teoria e a prática. Dessa forma, a interdisciplinaridade acontece pelas múltiplas determinações da realidade, ao contrário do que é realizado na Epistemologia da Prática, pelas disciplinas, com total abstração da realidade, da materialidade da vida. A prática social dos egressos que atuam nessas duas escolas nos permitiram desenhar um esquema que mostra a organização pedagógica que vem buscando materializar para construir a Escola do Campo.

Esquema 1: Organização Pedagógica da Escola do Campo.

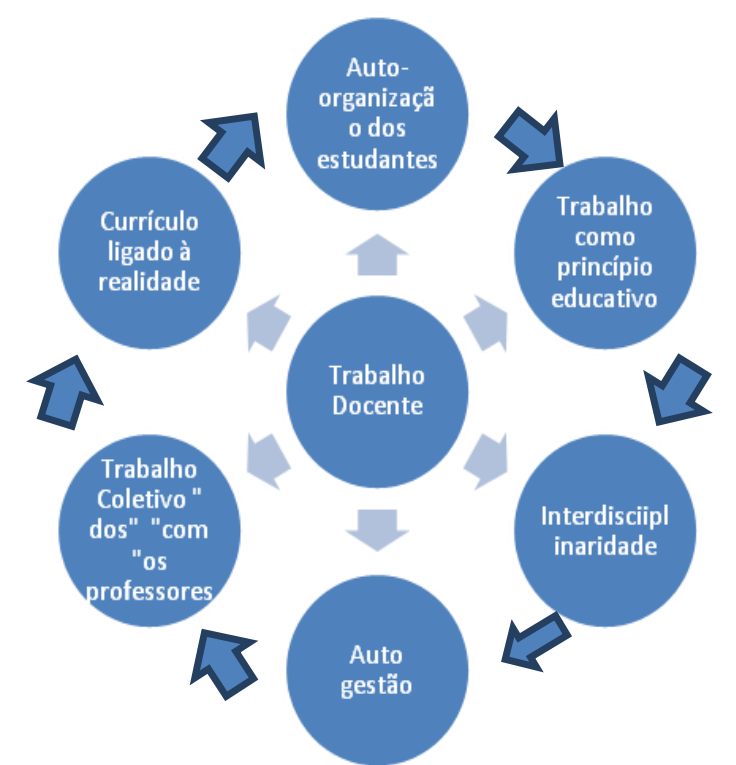

Fonte: Elaboração da autora, Pesquisa documental, 2016.

Essa matriz pedagógica tem como base a Epistemologia da Práxis, pois cada um dos princípios pedagógicos está baseado nas teorias socialmente referenciadas. E os conjuntos dessas teorias, historicamente acumuladas pela área das ciências sociais e naturais, permitem que o "movimento" da realidade 
pautada pelo trabalho, na sua concepção inicial, aquele em que o ser humano emprega sua força para produzir sua existência, transforme as Escolas Rurais em Escolas do Campo.

\section{Considerações finais}

A ação dos egressos do Curso de LEdoC/UnB, nos últimos 10 anos, tem contribuído significativamente com a Política Pública de Formação de Educadores, no sentido de compreender também a formação de professores com base na perspectiva crítico-emancipadora. Dessa forma, consideramos que:

- A Educação do Campo apresenta-se com um novo paradigma no cenário educacional brasileiro, o qual é pautado pelo debate da questão agrária, em contraposição à Educação Rural e ao modelo da reprodução capitalista para o Brasil. Esse paradigma vem se construindo por várias mãos e se firmando em um novo corpus com profundos fundamentos práticos e teóricos para ser objeto de estudo e pesquisa no pensamento pedagógico ocidental a partir da realidade brasileira, no qual os egressos da LEdoC/UnB têm contribuído a partir da sua formação inicial e continuada.

- $\mathrm{O}$ curso de LEdoC/UnB, no contexto da regulamentação do Procampo como política de formação de professores, vem apresentando "Elementos de transformar(ação) pedagógica" que têm repercutido na formação, organização e gestão da educação superior brasileira.

- Os processos de produção de conhecimento desencadeados pelos egressos do curso de Licenciatura em Educação do Campo, analisados a partir do discurso e de suas práticas pedagógicas, apresentam elementos que contribuem para afirmar a formação de professores do campo, no contexto da Epistemologia da Práxis.

$$
\text { Michelotti e Molina }
$$
reafirmam que esse processo é fruto do entendimento de que "as relações entre a Questão Agrária, a Educação do Campo e o Desenvolvimento Territorial, a Agroecologia e a Soberania Alimentar", no Brasil e na América Latina, têm como traço comum a centralidade dada ao que ocorre nas relações de produção no campo e aos diferentes sentidos dos processos formativos propostos pelas políticas públicas em andamento.

Consideramos que, no caminho percorrido com a presente pesquisa, nossa investigação pautou-se pela construção histórica e material da vida que encontra nas práticas educativas e no diálogo (Freire, 2015) a possibilidade de construção e transformação da história, nesse caso, pautando-nos pelos estudos e 
pesquisas desenvolvidas no coletivo de pesquisadores da Rede Universitas/Br e no Observatório da Educação Superior do Campo.

Consideramos, ainda, que os resultados da pesquisa realizada representam uma forma de resistência no nosso momento histórico, no qual o capitalismo toma uma forma global que requer o sacrifício e a extinção de seres humanos, agregando em sua raiz uma grande cadeia produtora. Essa cadeia se manifesta de várias formas econômicas e uma delas extermina e desapropria os camponeses e os sujeitos que vivem no campo: o modelo do agronegócio. Esse, através da produção de matérias primas em larga escala, ocupa dimensões extraordinárias de terras.

Dessa forma, a formação de professores para campo realizada a partir da práxis educativa dos egressos do curso de LEdoC/UnB, nos primeiros 10 anos de sua implantação, ofertou uma licenciatura que apresenta, em suas dimensões pedagógicas e de infraestrutura, uma nova forma de Organização do Trabalho Pedagógico pautada pela perspectiva crítica emancipadora.

Com fortes elementos de transformação e transgressões na Educação Superior Brasileira e pautado pela Alternância, pela formação por Área de
Conhecimento, pelo trabalho coletivo e pela relação Teoria e Prática, essa nova forma de organização está baseada nos princípios pedagógicos da Educação do Campo, que isolados não constituem a materialidade esperada para a formação de professores na Educação do Campo. Articulados, porém, eles incorporam o trabalho docente na perspectiva da Epistemologia da Práxis. São eles:

- Auto-organização dos estudantes;

- Trabalho como princípio educativo;

- Pesquisa como princípio formativo;

- Interdisciplinaridade;

- Mística;

- Autogestão;

- Trabalho Coletivo "dos" e "com" os professores e "entre" os educandos;

- Currículo ligado à realidade; e

- Relação teoria e prática como princípio de formação.

Esses princípios, articulados, vêm contribuindo para o processo de transformação da forma escolar "da escola pública, em duas relevantes dimensões da superação da lógica da escola capitalista: $O$ modo de produção de conhecimento e as relações sociais estabelecidas no âmbito da educação brasileira". (Freitas, 2006).

Assim, a Universidade de Brasília, a partir das relações estabelecidas e investigadas na formação de professores em uma perspectiva contra hegemônica 
tem contribuído e reunido um coletivo de professores que vem alterando as relações sociais na educação superior, outrora tomada pela lógica da individualidade e competitividade herdadas das bases capitalistas. O "trabalho coletivo" vem construindo o trabalho docente integrado que vise à superação da fragmentação do conhecimento também na Educação Superior.

\section{Referências}

Araújo, A. C. (2014). Discurso que constroem a Organicidade na Licenciatura em Educação do Campo (Monografia Especialização). Departamento de Teoria Literária, UnB, Guararema, São Paulo.

Brito, M. M. B. B. (2017). Formação de professores na perspectiva da Epistemologia da Práxis: análise da atuação dos egressos do curso de Licenciatura em Educação do Campo da Universidade de Brasília (Tese de Doutorado). Universidade de Brasília, Brasília.

Ferreira, M. J. L. (2015). Docência na Escola do Campo e Formação de Educadores: Qual o lugar do trabalho coletivo? (Tese de Doutorado). Universidade de Brasília, Brasília.

Freitas, L. C. (1995). Crítica da Organização do Trabalho Pedagógico e da Didática (8a ed.). São Paulo: Papirus.

Freitas, L. C. (2010). A Escola Única do Trabalho: explorando os caminhos de sua construção. In Cadernos do ITERRA, 15, Veranópolis - RS.
Freire, P. (2015). Pedagogia da Autonomia: saberes necessários à prática educativa. Rio de Janeiro/São Paulo: Paz e Terra.

Gramsci, A. (1999). Cadernos do Cárcere. Rio de Janeiro: Civilização Brasileira.

Luedke, A. M. S. (2013). A formação da criança e a Ciranda Infantil do MST (Dissertação de Mestrado). Universidade Federal de Santa Catarina, Florianópolis.

Lamosa, R. A. C. (2014). Estado, Classe social e educação no Brasil: uma análise crítica da hegemonia da associação brasileira do agronegócio (Tese de Doutorado). Universidade Federal do Rio de Janeiro, Rio de Janeiro.

Lima, P. D. (2015). A Ger'Ação Direta no DF: Reflexões sobre as lutas sociais em Brasília na primeira década século XXI. In Rêses, et al. (Orgs.). Universidade $e$ Movimentos Sociais (pp. 117-148). EDVCERE, Belo Horizonte: Traço Fino.

Marx, K. (1991). A ideologia alemã. São Paulo: Hucitec.

Machado, C. S. (2014). Formação de educadores e a construção da escola do campo: um estudo sobre a prática educativa no Colégio Estadual Vale da Esperança - Formosa/GO (Dissertação de Mestrado). Universidade de Brasília, Brasília.

Michelotti, F. (2014). Resistência camponesa e agroecologia. In Molina, M. C., et al. (Orgs.). Práticas contra hegemônicas na formação dos professores das Ciências Agrárias: reflexões sobre Agroecologia e Educação do Campo nos cursos do Pronera (pp. 60-87). Brasília: NEAD.

Mészáros, I. (2012). A educação para além do capital. São Paulo: Boitempo. 
Molina, M. C., Montenegro, J. L., \& Oliveira, L. L. N. A. (2009). Das desigualdades aos direitos: a exigência de políticas afirmativas para a promoção da equidade educacional no campo. Revista Raízes, 29(1), 174-190.

Molina, M. (2014). Análises de práticas contra-hegemônicas na formação de educadores: reflexões a partir do Curso de Licenciatura em Educação do Campo da UnB. In Souza, J. V. (Org.). O método dialético na pesquisa em educação (pp. 263-290). Campinas: Autores Associados.

Molina, M. C., \& Hage, S. (2015). Política de formação de educadores do campo no contexto da expansão da educação superior. Revista Educação em Questão. 51(37), 121-146.

Molina, M. C. (Org). (2017). Licenciatura em Educação do Campo e o ensino de Ciências Naturais: Desafios à promoção do trabalho docente interdisciplinar. Volume II. Brasília, Editora: UnB.

Molina, M. C., \& Hage, S. (2016). Riscos e potencialidades na expansão dos cursos de Licenciatura em Educação do Campo. RBPAE, 32, 805-828. Doi: https://doi.org/10.21573/vol32n32016.685 $\underline{77}$

Noronha, M. O. (2010). Epistemologia, formação de Educadores e práxis educativa transformadora. Quaestio, Sorocaba, SP, $12,5-24$.

Pistrak, M. M. (2009). A Escola-Comuna. São Paulo: Expressão Popular.

IBGE. (2014). Pesquisa Nacional por Amostra de Domicílios. Recuperado de: https://ww2.ibge.gov.br/home/estatistica/p opulacao/trabalhoerendimento/pnad2014/d $\underline{\text { efault.shtm }}$

Queiroz, J. B. (2004). Construção das Escolas Famílias Agrícolas no Brasil: ensino médio e educação profissional (Tese de Doutorado). Universidade de Brasília, Brasília.

Santos, S. P. (2012). A Concepção de Alternância na Licenciatura em Educação do Campo na Universidade de Brasília (Dissertação de Mestrado). Universidade de Brasília, Brasília.

Santos, E. M. (2016). Praticas pedagógicas de estudos da área de conhecimento de ciências da natureza e matemática do Curso de Licenciatura em Educação do Campo da UnB (Monografia de Especialização). SECADI/MEC, Brasília.

Silva, K.; A. C. P. C. (2011). A formação de professores na perspectiva críticoemancipadora. Linhas Críticas, 17(32), 1331.

Sguissardi, W. (2014). Relatório do estudo diagnóstico da política de expansão da (e acesso à) educação superior no Brasil 2002-2012. Piracicaba: UFSCAR.

Souza, A. G. S. (2016). Reflexões sobre uma pratica educativa de ciências da natureza e matemática inspirada na perspectiva Freiriana a partir da realidade do Assentamento Antônio ConselheiroTangará da Serra-MT (Monografia de Especialização). SECADI/MEC, Brasília.

Universidade de Brasília. (2009). Projeto Político Pedagógico LEdoC. Faculdade UnB Planaltina. Versão aprovada na $66^{\mathrm{a}}$ Reunião do Conselho da FUP. Brasília. Recuperado de: http://backfupunb.esy.es/images/stories/me dia/Apresentao/PPPI_FUP.pdf

Xavier, P. H. (2016). Matrizes formativas e organização pedagógica: contradições na transição da escola rural para escola do campo (Dissertação de Mestrado). Universidade de Brasília, Brasília. 
${ }^{\mathrm{i}}$ Auxílio pago aos estudantes no valor de $\mathrm{R} \$ 400,00$ (quatrocentos reais) para estudantes em situação de vulnerabilidade econômica, e R\$ 900,00 (novecentos reais) para estudantes pertencentes às comunidades indígenas e quilombolas. (Sobre essas ações, ver Resolução/CD/FNDE $n^{\circ} 13$, de 9 de maio de 2013.)

ii Moradia construída dentro da universidade para que os estudantes possam permanecer na universidade no período determinado para os estudos acadêmicos.

iii A principal formação realizada nos cursos de formação de professores atualmente é a realizada pela Epistemologia da Prática.

iv As informações referentes à produção do Agronegócio podem ser consultadas em <http://www.abag.com.br/>.

v Segundo Queiroz (2004), a Pedagogia da Alternância (PA) surgiu em 1935 em uma região chamada Lot-et-Garone no sudoeste da França, a partir da iniciativa de um grupo de agricultores, da referida região, que tentava responder à problemática daquela época em relação ao acesso à educação para a população do meio rural.

vi Pereira (2013) mostra como a criação dessa associação é um forte indicador para a emancipação e protagonismo dos egressos do curso de LEdoC uma vez que é associação formada a partir dos anseios de um grupo de professores egressos do curso de Licenciatura em Educação no Campo (LEdoC) oferecido pela Universidade de Brasília (UnB).

vii Professor da Escola Estadual Ernesto Che Guevara apresentou o assentamento para os professores do curso de especialização in loco.

viii Os pesquisadores são acadêmicos e professores da Universidade do Estado de Mato Grosso Unemat e realizaram um levantamento do padrão socioeconômico-cultural do Assentamento Antônio Conselheiro a partir da Agrovila Serra dos Palmares/MT, disponível em: http://need.unemat.br/3 forum/artigos/16.pdf.

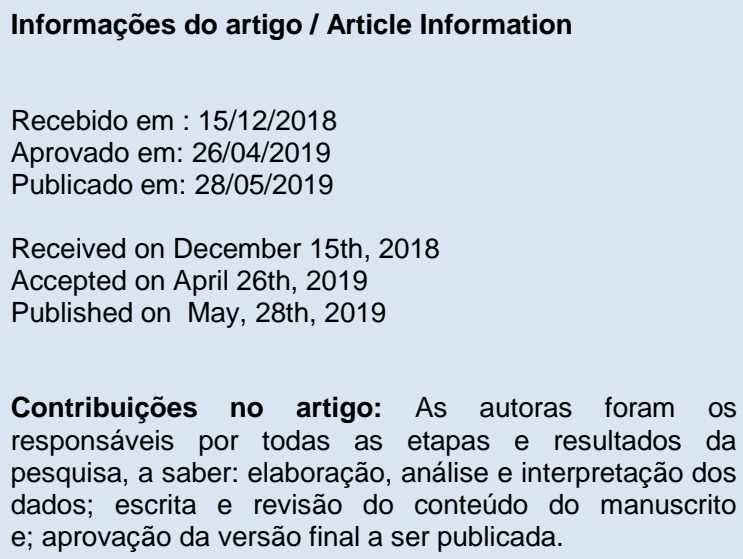

Contribuições no artigo: As autoras foram os responsáveis por todas as etapas e resultados da pesquisa, a saber: elaboração, análise e interpretação dos dados; escrita e revisão do conteúdo do manuscrito e; aprovação da versão final a ser publicada.

Author Contributions: The authors were responsible for the designing, delineating, analyzing and interpreting the data, production of the manuscript, critical revision of the content and approval of the final version to be published.

Conflitos de interesse: As autoras declararam não haver nenhum conflito de interesse referente a este artigo.

Conflict of Interest: None reported.

Orcid

Márcia Mariana Bittencourt Brito

(iD) http://orcid.org/0000-0001-9966-8534

\author{
Mônica Castagna Molina \\ (iD) http://orcid.org/0000-0001-9901-9526
}

\section{Como citar este artigo / How to cite this article}

APA

Brito, M. M. B., \& Molina, M. C. (2019). Reflexões sobre os egressos do curso de Licenciatura em Educação do Campo da Universidade de Brasília: os elementos para "Transformar (ação) Pedagógica" na Educação Superior. Rev. Bras. Educ. Camp., 4, e6291. DOI: http://dx.doi.org/10.20873/uft.rbec.e6291

\section{ABNT}

BRITO, M. M. B.; MOLINA, M. C. Reflexões sobre os egressos do curso de Licenciatura em Educação do Campo da Universidade de Brasília: os elementos para "Transformar (ação) Pedagógica" na Educação Superior. Rev. Bras. Educ. Camp., Tocantinópolis, v. 4, e6291, 2019. DOI: http://dx.doi.org/10.20873/uft.rbec.e6291 